\title{
SÚČASNÝ STAV LOKALIZÁCIE VIDEOHIER NA SLOVENSKU
}

\author{
MÁRIA KOSCELNÍKOVÁ
}

\begin{abstract}
The Present State of the Localization of Video Games in Slovakia In Slovakia there is no tradition of localisation of video games. Foreign countries, however, have much to offer regarding the academic environment and practical outcomes. The Slovak market does not even offer Slovak localisations of video games for children who are entitled to Slovak localisations pursuant to Slovak legislation. Our paper aims to examine the issue of Slovak video game localisation, present the most serious results of our research, and offer goals for future research aimed at specific aspects of localisation of video games for Slovak children and their multimodality.
\end{abstract}

Keywords: video game; multimodality; localisation; audiovisual translation; children recipient

\section{Úvod}

Audiovizuálny preklad je v slovenskom akademickom priestore rezonujúcou oblastou translatológie, ktorej sa dostáva čoraz viac pozornosti. V prípade lokalizácie videohier ešte stále nemôžeme povedat to isté, aj ked’ od ich vzniku ubehlo už viac než polstoročie a tradícia spojená s ich prekladom bola započatá už dávno. V zahraničí je lokalizácia videohier bežnou záležitost’ou. Videohry sa lokalizujú do väčších európskych či ázijských jazykov a ich výskumu sa venuje mnoho osobností zahraničného akademického priestoru, ktoré pravidelne publikujú nové zistenia i teoretické východiská. Lokalizácia videohier sa vyučuje na mnohých zahraničných univerzitách, či už ako študijný program, alebo ako volitelný predmet, no nedá sa povedat', že by situácia na Slovensku bola podobná. Lokalizácii videohier sa u nás venuje vel’mi málo výskumníkov, nevyučuje ju žiadna univerzita ani ako program, ani ako predmet, a na slovenskom trhu nájdeme iba mizivý počet videohier lokalizovaných do slovenčiny. Tieto dôvody, ako i naša záluba v nich kultúrnom prvku nás podnietili skúmat túto problematiku, ktorej sa venujeme od roku 2015.

V tomto príspevku sa zameriame na problematiku lokalizácie videohier so zretelom na súčasný stav lokalizácie videohier na Slovensku, predostrieme najzávažnejšie zistenia v doterajšom výskume a priblížime náš súčasný výskum a ciele do budúcna. V prvej kapi- 
tole načrtneme stručnú charakteristiku skúmanej problematiky a interaktivitu videohier, kvôli ktorej bude zrejme ešte dlho trvat', kým sa výskum videohier rozbehne a ustáli v slovenskej translatológii. V druhej kapitole priblížime našu orientáciu na detského recipienta a východiská, vd’aka ktorým má lokalizácia videohier pre deti budúcnosṫ. V tretej kapitole poukážeme na závažné zistenia nášho doterajšieho výskumu. Túto kapitolu členíme na menšie podkapitoly. V prvej podkapitole sa venujeme teórii lokalizácie, rozoberáme stav výskumu lokalizácie herného (aj neherného) softvéru v slovenskom akademickom priestore a zároveň poukazujeme na skutočnost', že lokalizácia je komplexnejší systém a preklad je iba jeho súčastou. V druhej podkapitole rozoberáme legislatívne ukotvenie lokalizácie a poukazujeme na súčasnú (ne)prítomnost’ lokalizácií videohier do slovenčiny, so zretel'om na detské videohry vo vybraných slovenských obchodoch, ponúkajúcich tento typ produktov. Závažnost' zistení umocňuje aj skutočnost', že amatérskych prekladov videohier je na Slovensku viac ako profesionálnych. V tretej podkapitole poukazujeme na nemožnost' dopátrania sa k slovenským prekladatel’om videohier a vo štvrtej podkapitole prinášame zaujímavé zistenia $\mathrm{z}$ dotazníkového prieskumu, ktorý sme realizovali v rámci nášho predošlého výskumu.

Náš článok zakončujeme štvrtou kapitolou, venovanou súčasnému výskumu lokalizácie videohier do slovenčiny, ktorá je orientovaná na detského recipienta a rozoberáme ciele našej dizertačnej práce. Dúfame, že naša práca zaujme akademickú obec a bude ju inšpirovat k dalšiemu výskumu lokalizácie videohier.

\section{Stručná charakteristika skúmanej problematiky}

Zábava je neodmyslitel’nou súčastou našej existencie. S rozvojom technológií sa, prirodzene, snažil inovovat formy zábavy aj zábavný priemysel, preto Steve Russell, študent Inštitútu Technológií v Massachusetts, reagoval na danú situáciu a v roku 1961 vytvoril prvú interaktívnu videohru Spacewar!. Russell sa ani len nepokúšal získat’ ocenenia či autorské práva na svoju hru, vytvoril ju s úmyslom ukázat, že je to možné (Kent 2001). Tento čin položil základy toho, čomu dnes vravíme videohra. Charakteristike videohry sme sa venovali už v našom predchádzajúcom výskume (Koscelníková 2017) a v rámci nášho výskumu operujeme s pojmom videohra ako so strešným pojmom pre akúkolvek videohru, ktorú je možné hrat prostredníctvom elektronického zariadenia. Do tejto charakteristiky preto spadajú arkádové hry, počítačové hry, konzolové hry, mobilné i online hry. V našom výskume chceme taktiež upriamit pozornost' aj na pojem multimediálny interaktívny zábavný softvér, ktorý zaviedol Bernal-Merino (2015), aby zdôraznil jeden z dôležitých prvkov videohry, ktorý ju líši od audiovizuálnych diel, a to interaktivitu, ktorá dáva videohrám pridanú hodnotu.

Videohry sú teda multimediálne diela, ktoré okrem scénickej časti (video a audio), ktorej textovú formu predstavujú titulky, obsahujú aj čast' interaktívnu, ktorá so sebou častokrát prináša množstvo d’alšieho textu, ktorý je potrebné preložit. Preklad videohry však spadá do rozsiahlejšieho cyklu, ktorý sa nazýva lokalizácia. Tento proces zahŕňa viac ako preklad. Aj to je zrejme dôvodom, prečo si preklad videohier ešte stále nenašiel miesto v slovenskej translatológii. Lokalizáciu videohier preto považujeme nielen za súčast’ audiovizuálneho prekladu (dabing, titulkovanie), no i za súčast’ umeleckého pre- 
kladu (preklad textov), odborného prekladu (podla typu hry, napr. simulátory) a stotožňujeme sa s Bernal-Merinom (2015), ktorý poukazuje na rôznorodost’ a mnohotvárnost’ videohier, ktoré od prekladatela vyžadujú nadmerné množstvo kompetencií. Azda táto neuchopitel'nost', nejednoznačnost' a nezaraditel'nost' budú viest’ v budúcnosti k tomu, aby sa lokalizácia, resp. preklad videohier presadil ako samostatný typ prekladu.

Napriek tomu, že videohry sa v súčasnosti tešia vel'kej oblube, ich lokalizácia do slovenčiny nie je frekventovaná. Slovenská legislatíva aktuálne nariaduje lokalizáciu detských videohier, no realita tomu nezodpovedá, preto sme sa rozhodli našu dizertačnú prácu a výskum upriamit’ práve na detského recipienta.

\section{Deti ako budúcnost' slovenského prekladu videohier}

Ak do vyhladávača Google zadáme termín videohra, ponúkne nám obrázky, ktoré sa vo väčšine prípadov spájajú s mladým chlapcom sediacim za počítačom. Takéto stereotypné vnímanie cielového prijímatela videohier už v dnešnej dobe neplatí. Napriek tomu sa v súvislosti s pojmom videohra v rôznych publikáciách o videohrách, ako aj v Kentovej publikácii z roku 2001, často spomínajú deti. Deti sú zároveň dôvodom, prečo vzniklo hodnotenie obsahu hier podla veku. Aj napriek tomu, že je detom vo videohernom priemysle venovaná tak vysoká pozornost', sa priemerný vek hráča za posledných 14 rokov pohybuje medzi vekom 30-35 rokov, ako to uvádzajú napríklad štatistiky Essential Facts about the Computer and Video Game Industry (Základné fakty o počítačovom a videohernom priemysle) spoločnosti The Entertainment Software Association za rok 2004-2018. Okrem iného sa práve tento typ štatistiky zameraný na americký trh, ktorý patrí k najväčším videoherným trhom, zameriava na rôzne aspekty hráčov videohier a tieto aspekty sú často nejednotné alebo svojím spôsobom vyčnievajúce. Aj táto rozmanitost' hráčov videohier, ako aj videohier samotných, nás podnietila skúmat' lokalizáciu videohier.

V našom doterajšom výskume sme sa venovali lokalizácii videohier so zretelom na ich titulkovanie do slovenčiny. Kedže tento typ prekladu sme na Slovensku začali skúmat' ako prví, mali sme širokú škálu možností, no velmi málo slovenských teoretických východísk. Zahraničné publikácie nám, naopak, ponúkli bohatú paletu tém. Zahraniční výskumníci, ako napr. Bernal-Merino, O’Haganová či Mangironová, sa lokalizácii videohier venujú už viac ako 10 rokov. V neposlednom rade sa v zahraničí usporadúvajú aj konferencie venované prekladu videohier, ako napríklad Fun for All. Pri výbere témy sme vychádzali z dostupných verzií hier v slovenčine a $\mathrm{z}$ najfrekventovanejšej formy ich prekladu - titulkovania. Po hlbšom pátraní sme však zistili, že na slovenskom trhu je obrovská dominancia amatérskych prekladov. Táto skutočnost’ je spôsobená nedostatočným zastúpením videohier v slovenskej legislatíve, ktorá sa lokalizácii videohier takmer nevenuje, kedže vníma videohry ako multimediálne diela, ktoré sú v porovnaní s audiovizuálnymi dielami spomínané velmi málo. Pri podrobnom preštudovaní slovenskej legislatívy sme zistili, že lokalizácia videohier do slovenčiny nie je povinná pre všetky kategórie hier, a že jediná obligácia sa týka detského recipienta. Štvrtá čast’ zákona č. 40/2015 Z. z. o audiovízii, $\$ 15$ Osobitné ustanovenia o jazykovej úprave v odseku 3 nariaduje vyhotovit slovenskú jazykovú úpravu hier pre deti vo velmi komplikovanom znení: „Distributér mul- 
timediálneho diela, ktorý verejne rozširuje multimediálne dielo, ktoré je podla jednotného systému označovania klasifikované ako vhodné pre vekovú skupinu maloletých do 12 rokov $v$ pôvodnej jazykovej úprave inej ako v slovenskej jazykovej úprave, ak toto audiovizuálne dielo nie je v pôvodnej jazykovej úprave splñajúcej požiadavku základnej zrozumitelnosti z hladiska štátneho jazyka, je povinný zabezpečit pre toto multimediálne dielo aj slovenskú jazykovú úpravu."

Z uvedeného zákona vyplýva, že by distribútori videohier pre deti mali zabezpečit’ slovenskú verziu hry, pokial' taká hra nie je pôvodne vyhotovená v českom jazyku (napr. Krtek, Botanicula, Vietcong, Rákosníček a pod.). Napriek tomu sa na trhu stretávame s detskými hrami typu Barbie, Winx, alebo rôznymi inými hrami, napríklad od spoločnosti Disney, ktoré nie sú v pôvodnom jazyku českom, no nie sú preložené do slovenského jazyka, iba do češtiny. Situáciu komplikuje aj nejednoznačný systém označovania hier, nedostatočná formulácia požiadaviek pre distribútorov, nefunkčný mechanizmus kontroly dodržiavania zákona a mnohé faktory, ktoré sa chystáme sledovat počas nášho doktorandského štúdia.

Kedže nám videohry pre deti a ich preklad nie sú lahostajné a táto téma nás zaujíma, rozhodli sme sa ich skúmat', a to v rámci tretieho stupňa nášho štúdia. Vychádzali sme nielen z (ne)funkčnej platnej legislatívy, ale aj z psycholingvistického hladiska. Vd’aka platnej legislatíve sú deti istou budúcnostou lokalizácie videohier do slovenčiny. Vznik tradície lokalizácie videohier do slovenčiny by mala podporovat’ aj skutočnost', že na Slovensku už máme nielen zákonom danú, ale i ustálenú tradíciu prekladu animovaných filmov pre deti do slovenčiny. $Z$ tohto dôvodu usudzujeme, že prípadné videoherné adaptácie rôznych filmov pre deti by mohli poslúžit ako podkladový materiál na ich preklad. Taktiež sa opierame o potrebu rozvoja jazyka maloletého, ktorý má na základe zákona č. 245/2008 Z. z. o výchove a vzdelávaní nadobudnút’ schopnost' komunikovat' v štátnom/ materinskom jazyku. „Už od narodenia sa malé diet’a snaží komunikovat’ jemu najbližším spôsobom, t. j. krikom. Postupne sa jeho rečové schopnosti zdokonalujú, až prichádza do materskej školy, kde by sa mali jeho rečové (komunikatívne) schopnosti rozvíjat" (Chlebeková 2014: 6). Myslíme si, že kontakt dietata s materinským jazykom je nesmierne dôležitý pre další vývoj jeho reči a vd’aka popularite videohier by mal byt dietatu umožnený aj prostredníctvom ich hrania v slovenskom jazyku.

Po zhrnutí všetkých argumentov sú deti dôležitým prijímatelom a budúcnostou prekladu videohier do slovenčiny $\mathrm{z}$ nasledujúcich troch dôvodov:

1. psycholingvistické hladisko

2. nastolená prekladatel’ská tradícia prekladu diel pre detského recipienta do slovenčiny

3. platná legislatíva

Neexistencia tohto typu prekladu prináša množstvo rizík. Už v súčasnosti spôsobuje nedostatok prekladov do slovenčiny v audiovízii infiltráciu mnohých inojazyčných slov, najmä bohemizmov, do reči dietata, ktoré ich používa namiesto slovenských slov počas bežnej komunikácie v slovenčine. Máme na mysli detské televízne stanice, videohry či detské časopisy, ktoré neponúkajú slovenskú verziu. Dané skutočnosti sa pokúsime zmapovat aj prostredníctvom dotazníka, ktorý rozpošleme rodičom detí a budeme sledovat či deti používajú v bežnej reči bohemizmy, v akom jazyku hrávajú videohry a pod. Netvrdíme, že učenie sa nových slov v cudzích jazykoch je pre deti zlé či neprospešné, no chceme poukázat' na to, ako lahko sa cudzie slová dostávajú do slovnej zásoby dietata 
a ako vedia ovplyvnit jeho materinský jazyk v ranom veku. Vychádzajúc aj z tejto skutočnosti sa domnievame, že slovenské preklady videohier pre deti, by mohli podporovat’ obohacovanie slovnej zásoby dietata. Moderná doba a s ňou spojený vplyv angličtiny, však môže v blízkej budúcnosti značne skomplikovat’ potrebu prekladu videohier pre deti. Na Slovensku však máme stále platnú legislatívu, ktorá by sa mala dodržiavat'.

\section{Závažné zistenia vo výskume lokalizácie videohier}

\subsection{Lokalizácia videohier stratená v slovenskom výskume}

Lokalizácia videohier, ako súčast’ translatológie, zatial’ v slovenskom akademickom priestore nebola predmetom rozsiahlejšieho výskumu. V porovnaní s odborným, umeleckým či audiovizuálnym prekladom a ich teoretickými východiskami, ešte nemožno tvrdit, že lokalizácia videohier má v slovenskej translatológii stále a ukotvené miesto. To isté vieme tvrdit’ o lokalizácii neherného softvéru. V doterajšom výskume (Koscelníková 2017) sme zistili, že lokalizácia si nachádza cestu k slovenskej akademickej obci dost’ tažko. Doteraz sa jej venovala najmä Rakšányiová (2012) so zretelom na webové stránky. Prvé zmienky o lokalizácii videohier nachádzame v práci Janecovej (2014), ktorá poukázala nato, že lokalizácii videohier sa v rámci výskumu nevenuje dostatočná pozornost'. Situácia je však v súčasnosti priaznivejšia, lokalizácii od r. 2018 venovali zvýšenú pozornosṫ Marčanová (2018), Kulbak (2018) či Cabajová (2019). Prvú kritiku prekladu videohry priniesla Koscelníková (2018b). Na podujatí Letná škola prekladu, ktorú každoročne organizuje Slovenská spoločnost’ prekladatelov umeleckej literatúry v Pieštanoch, nastolil diskusiu o lokalizácii aj Kabát, ktorý sa venuje lokalizácii softvéru aj zo všeobecného hladiska (2019). Spolu s Koscelníkovou započali plodnú diskusiu medzi mnohými osobnostami slovenskej akademickej obce, ako aj medzi praktikmi. Dúfame, že je to slubným odrazovým mostíkom a že sa lokalizácii videohier, ako aj lokalizácii samotnej, bude venovat' čoraz väčšia pozornost'.

Okrem nedostatočnej výskumnej pozornosti nachádzame problémy už pri samotnom vnímaní pojmu lokalizácia v kontexte prekladu. Pojem lokalizácia sme už podrobnejšie rozobrali v predošlom výskume (Koscelníková 2018a: 61). Medzi tradičnou lokalizáciou a lokalizáciou videohier vyvstáva mnoho rozličných aspektov, no spoločným znakom je, že ide (nielen) o preklad softvéru. Problém však nastáva pri pojmosloví, pretože lokalizácia nezahŕňa iba preklad. Podla Chandlerovej a Demingovej (2012) je lokalizácia videohier prekladom jazykových aktív do iných jazykov. No preklad videohry nie je iba o samotnej lokalizácii, ale o väčšej skupine úkonov, ako je napríklad internacionalizácia či kulturalizácia. Podl’a organizácie LISA (2003) zahŕňa lokalizačný proces ovela viac, než iba prekladový proces a celý proces je označovaný tiež skratkou GILT - Globalizácia, Internacionalizácia, Lokalizácia a Translácia.

V rámci procesu GILT ide o výrobu a adaptovanie produktu takým spôsobom, aby pôsobil ako produkt krajiny, do ktorej je distribuovaný. Na to je potrebné globalizovat ho, teda „vykonat všetky potrebné technické, finančné, manažérske, zamestnanecké, marketingové a ostatné firemné rozhodnutia, ktoré zlahčia lokalizáciu [...] Globalizácia zahŕňa kompletný a dobre štruktúrovaný životný cyklus vývoja produktu od analýzy globál- 
neho a lokálneho produktu, cez globalizáciu a lokalizáciu produktu, končiac podporou a spätnou väzbou na lokalizované produkty (LISA 2003: 5, vlastný preklad). Chandlerová a Demingová (2012) považujú za ciel’ internacionalizácie „vytvorit’ projekt, ktorý je možné lokalizovat jednoducho a s minimálnym úsilím na strane vývojára - rovnaké herné funkcie, funkčnost’ a hráčska skúsenost’ sú prítomné vo všetkých medzinárodných verziách hry. Medzinárodní používatelia majú mat pocit, že bol produkt vyrobený práve pre nich a že zažívajú rovnakú skúsenost̉ ako hráči originálu hry“ (Chandlerová - Demingová 2012: 4, vlastný preklad). Okrem internacionalizácie nezabúdajú autorky ani na kulturalizáciu, ktorá je nesmierne dôležitým prvkom celého procesu globálnej distribúcie videohry a „zaistuje, aby hráči hry neboli odradení od hrania takou častou obsahu hry, ktorá je nevhodná či dokonca urážlivá (Chandlerová - Demingová 2012: 19, vlastný preklad). Zaujímavostou v rámci lokalizácie je aj myšlienka, ktorú spomenul Bernal-Merino na kurze lokalizácie videohier (Londýn 2019) a to, že sa prekladá text, no lokalizuje sa celý produkt. Táto problematika a začlenenie prekladu do procesu lokalizácie, mohli spôsobovat' doterajší nezáujem či neprítomnost’ lokalizácie v slovenskom translatologickom výskume, ako aj ich neprítomnost’ v didaktike prekladu a tlmočenia. Žijeme však v dobe technológií a tak ako napreduje svet, tak by aj slovenská translatológia mala reagovat na existenciu lokalizácie videohier, ktorej sa v zahraničí už dlhšie venuje pozornost'. Skutočnost', že videohry sú softvér, je d’alšou prekážkou, ktorá komplikuje ich uchopitel’nost’ a zaraditelnost' už k tradičným typom prekladu.

Podla O’Haganovej a Mangironovej (2006) majú lokalizácia samotná a lokalizácia videohier spoločnú črtu, ktorou je softvérová stránka. „Obe zahŕňajú kombináciu prekladu jazyka a softvérového inžinierstva, pričom prekladané textové vlákna nemusia v softvéri nasledovat' za sebou [...]. Obe sa riadia podobným lokalizačným cyklom, ktorý ideálne začína internacionalizáciou a končí procesom hodnotenia kvality pred vydaním finálneho produktu“ (12, vlastný preklad). Táto kombinácia je možnou odpoved’ou na otázku, prečo si ešte lokalizácia videohier nenašla miesto v slovenskej translatológii a prečo sa o nej začalo hovorit’ len nedávno. Preklad videohier sa na Slovensku vytráca preto, lebo na školách vyučujúcich tvorbu a dizajn hier ${ }^{1}$ sa o jazykovom aspekte hry či jej lokalizácii vôbec neuvažuje. Práve preto je lokalizácia videohier zatial' neuchopenou oblastou výučby a výskumu na rozdiel od zahraničia, kde sa jej okrem spomenutých autorov venuje napr. aj B. Esselink (2000) či A. Pym (2004, 2013). V neposlednom rade prispieva $\mathrm{k}$ nepriaznivej situácii aj nedostatočné uchopenie a vymedzenie povinností v slovenskej legislatíve, ktorej sa budeme venovat’ v nasledujúcej podkapitole.

\subsection{Lokalizácia videohier stratená v legislatíve i v translatológii}

Jednou z d’alších a najzávažnejších prekážok lokalizácie videohier do slovenčiny je nepriaznivá legislatíva Slovenskej republiky. Videohry sa v nej spomínajú iba okrajovo v zákone č. 40/2015 Z. z. o audiovízii a jedinú obligáciu môžeme nájst’ v $\$ 15$, odsek 3 . $\mathrm{Na}$ žiadnom inom mieste sa distribútorom videohier nekladie povinnost’ prekladat' ich.

1 Webová stránka Fakulty masmediálnej komunikácie: https://fmk.sk/tedi [cit. 31. 1. 2019]; Rozpis predmetov Katedry informatiky UK, BA: http://new.dcs.fmph.uniba.sk/index.php/Predmety? _method=detail\&_key=ECTSkod\&ECTSkod=2-INF-263 [cit. 31.1. 2019]. 
Myslíme si, že ide o d’alší faktor, ktorý bráni vzniku prekladov videohier do slovenčiny. Zarážajúcou skutočnostou však je, že napriek legislatíve sa preklady videohier pre deti do slovenčiny nerealizujú takmer vôbec. V našom predošlom výskume sme sledovali aj počty ponúkaných hier online obchodu progamingshop.sk, ktorý mal k aprílu $2018 \mathrm{v}$ ponuke 196 hier pre deti, z ktorých bolo 41 hier v origináli, príp. inej jazykovej podpore ako českej či slovenskej, 146 hier bolo v češtine a $9 \mathrm{v}$ slovenčine. Napriek tomu počet ponúkaných hier nekorešpondoval so skladovou dostupnostou. V januári 2019 sme so zretelom na detské hry skúmali portfólio daného obchodu opät - obchod ponúka 53 hier, z toho $10 \mathrm{v}$ angličtine, $15 \mathrm{~s}$ českým dabingom, 27 s českými titulkami a iba $\mathbf{1}$ hru so slovenským dabingom. Opät', ponuka nekorešponduje so skladovými zásobami a z 53 hier v kategórii „detské hry“ sú na sklade iba dve. Ako výskumná vzorka je obchod progamingshop.sk zatial najvhodnejší, kedže ponúka iba fyzické kópie hier a neponúka digitálny obsah vo forme stahovatelných doplnkových častí hry, ktorý je možné zakúpit aj z iných zdrojov. ${ }^{2}$

Ako d’alšia výskumná vzorka nám poslúžil e-shop brloh.sk. ${ }^{3}$ Pri skúmaní ponuky hier sme zistili, že obchod ponúka prevažne digitálne verzie hier, ktoré sa dajú kúpit’ cez herné platformy Steam ${ }^{4}$ alebo Origin ${ }^{5}$, ktoré nie sú slovenskými distribútormi. Boli sme však sklamaní, pretože zo 102 ponúkaných detských videohier, z čoho bolo 19 fyzických a 83 digitálnych verzií hier, nebola žiadna po slovensky. 92 hier bolo v angličtine, 9 hier obsahovalo české titulky a jedna hra nemala uvedený jazyk, do ktorého bola lokalizovaná. Napriek argumentu, že hry neponúkajú slovenskí distribútori, je toto číslo alarmujúce a poukazuje na nedodržiavanie legislatívy. Dostávame sa však k problematike distribúcie digitálneho obsahu. Pokial' slovenský obchod brloh.sk predáva videohry, ktoré poskytuje Steam, platí preň $\$ 15$ odsek 3 zákona o audiovízii č. 40/2015 Z. z. Takisto však tento zákon platí aj pre Steam, kedže pôvod distribútora zákon nešpecifikuje, to znamená, že ide o akéhokolvek distribútora, ktorý distribuuje hry na Slovensku. Ďalšou skutočnostou je, že doteraz sa nikto nezaoberal problematikou neexistencie hier v slovenskom jazyku, preto usudzujeme, že zrejme nemáme žiaden kontrolný orgán, či systém sankcií, ktorý by zamedzoval nerešpektovaniu zákona. Takisto v rámci online platforiem typu Steam, ktoré distribuujú hry celosvetovo, nie je v stanovách spoločnosti explicitne napísané, že ich videohry sú distribuované na Slovensku, kedže si ich síce môže zakúpit slovenský recipient, no nemusí sa na území Slovenska nachádzat’ a tak je cielové „územie“ nešpecifikované. Môže sa však stat’, že niektoré videohry obsahujú aj slovenskú lokalizáciu, no kedže slovenčina nie je jazykom, do ktorého je platforma Steam preložená, takáto informácia sa v popise hry neobjaví. Máme na mysli napríklad hru Euro Truck Simulator 2, ktorá obsahuje slovenskú lokalizáciu, no v popise hry na Steame o nej nie je žiadna zmienka. ${ }^{6}$ Tieto skutočnosti bránia výskumu, ale aj kritike prekladu videohier do slovenčiny. V porovnaní s mizivým počtom profesionálnych lokalizácií vieme nájst’ bohatú ponuku videohier s amatérskym prekladom do slovenčiny, ktorých počet k januáru 2019 presiahol závratné číslo $300 .^{7}$

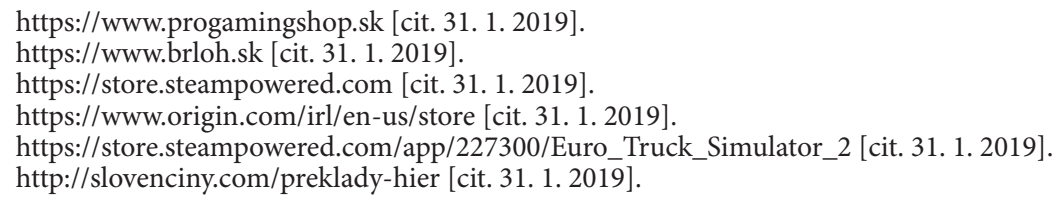




\subsection{Prekladatelia videohier stratení v preklade/na trhu}

Ak sa nám na slovenskom trhu podarilo objavit’ videohry lokalizované do slovenčiny, daný distribútor bol už zvyčajne nefungujúcou spoločnostou, ktorej kontaktné údaje sú nedohladatelné, webové stránky neexistujúce a emailové adresy neplatné. Ak sa nám aj podarilo dopátrat' k daným osobám, nevedeli si spomenút na konkrétne meno prekladatela, takže nedokážeme zistit’ o koho išlo, či bol profesionál alebo amatér, ani aké boli dôvody konkrétnych prekladatel'ských riešení. Ako sme už spomínali v kritike prekladu videohry Sherlock Holmes vs. Arsène Lupin (Koscelníková 2018b) „na rozdiel od kníh, kde v tiráži môžeme nájst’ meno prekladatela, na obaloch videohier by sme meno prekladatel’a hladali márne“ (Koscelníková 2018b: 28). Tajná identita prekladatela, ktorá znemožňuje hladký priebeh výskumu lokalizácie videohier do slovenčiny, značne komplikuje náš výskum.

\subsection{Záujem hráčov i prekladatel’ov o slovenčinu vo videohrách}

V rámci našej diplomovej práce sme sa rozhodli skúmat’ lokalizáciu videohier do slovenčiny z pohladu prekladatel'ov i hráčov videohier. Podarilo sa nám oslovit’ 36 prekladatelov vo veku od 18 do 62 rokov a 164 hráčov vo veku od 14 do 34 rokov. Každá skupina vyplnila osobitný dotazník tvorený z otvorených i uzavretých otázok. Za najzávažnejšie zistenia považujeme napríklad skutočnost', že prekladatelia ponuky na preklad videohier nedostávajú, čo korešpondovalo so stavom trhu. Bohužial', v súčasnosti sa situácia nezmenila. Na otázku, či by prekladatelia prijali ponuku na preklad videohry sa väčšina opýtaných prekladatelov vyjadrila kladne. Čo sa týka hráčov, na otázku „Ak by existovali videohry v slovenčine, zahrali by ste si hru radšej po slovensky?“ 47 \% opýtaných hráčov odpovedalo pozitívne, pričom viacerí sa v doplňujúcej otvorenej otázke vyjadrili, že v súčasnosti už originálu hry (väčšinou v angličtine) rozumejú, no v časoch, ked’ jej nerozumeli tak dobre, by ocenili slovenčinu. Vzhladom na rozrastajúci sa počet anglicky hovoriacich ludí toto zistenie iba poukazuje na skutočnost', že starší recipient nebude mat' problémy s porozumením videohry $\mathrm{v}$ angličtine. $\mathrm{Z}$ tohto dôvodu sme sa rozhodli upriamit pozornost' na stále pretrvávajúcu problematiku neexistencie slovenskej lokalizácie detských videohier a venovat’ sa jej v našej dizertačnej práci.

\section{Súčasný výskum a ciele do budúcna}

Napriek nepriaznivej situácii sa výskumu lokalizácie videohier začína venovat’ väčšia pozornost'. Ked’̌̌e slovenská legislatíva nariad'uje preklad videohier iba pre detských recipientov, rozhodli sme sa túto problematiku skúmat’ a venovat sa lokalizácii a prekladu videohier pre detského recipienta, konkrétne jej špecifikám z teoretického aj praktického hladiska. Neprítomnost' slovenčiny v detských videohrách, ktoré sú v súčasnosti l’ahko dostupné, spôsobuje niekol'ko faktorov, ktorým sa chceme venovat v budúcom výskume. Videohry pre deti v slovenčine majú potenciál cibrit’ a rozširovat slovnú zásobu detského recipienta. Kedže na Slovensku sa výskumu lokalizácie detských videohier ešte nikto 
nevenoval, pokúsime sa híbkovo analyzovat’ a spracovat dostupné teoretické východiská lokalizácie a prekladu videohier pre detských recipientov, z ktorých vyvodíme špecifiká lokalizácie videohier. V našom budúcom výskume budeme kombinovat kvalitatívny a kvantitatívny výskum. Okrem hlavnej časti nášho výskumu poukážeme aj na čiastkové problémy, ktoré rezonujú v súvislosti s lokalizáciou a prekladom videohier pre detských recipientov na Slovensku a budeme hladat ich riešenia.

Jedným z týchto problémov je aj neexistencia slovenských prekladov videohier pre detských recipientov a nerešpektovanie odseku 3, $\$ 15$ zákona č. 40/2015 Z. z. o audiovízii. V súvislosti s legislatívou upravujúcou lokalizáciu a preklad nachádzame nejednoznačnost’ vekového ohraničenia v súvislosti s odsekom 3, \$15 zákona č. 40/2015 Z. z. o audiovízii, kedže v rámci Európy sa distribúcia videohier riadi podla organizácie Pan European Game Information (PEGI), ktorá má ratingové kategórie videohier rozdelené takto: kategória 3 - pre všetky vekové kategórie (od 3 rokov); kategória 7 - od 7 rokov; kategória 12 - od 12 rokov; kategória 16 - od 16 rokov a kategória 18 - od 18 rokov. ${ }^{8} \mathrm{~V}$ porovnaní so slovenskou legislatívou, ktorá vníma detského recipienta ako maloletého do 12 rokov, toto hodnotenie nevníma detského recipienta ako výlučného recipienta videohry. Daná nejednoznačnost̉ ponúka distributérom možnost’ videohry nelokalizovat'. Na Slovensku zároveň neexistuje žiaden kontrolný orgán, ktorý by dohliadal na funkčnost̉ legislatívy. Chceme poukázat’ na to, že na Slovensku nemáme žiadnu doložku či zákon, ktorá by zohladnila aj iné hodnotenie videohier podla veku. Aj preto na pultoch obchodov chýbajú videohry so slovenskou lokalizáciou napriek tomu, že hra je určená aj pre deti do 12 rokov.

Príbuznost' slovenčiny a češtiny má markantný vplyv na neprítomnost’ slovenských prekladov (nielen) detských videohier na slovenskom trhu, najmä kvôli legislatívnemu vnímaniu češtiny ako zrozumitel’ného jazyka podla zákona č. 270/1995 Z. z. o štátnom jazyku SR, čo je dôsledkom spoločnej histórie krajín. Tento jazykový pár chceme porovnat s legislatívnym ukotvením jazyka a lokalizácie videohier v iných európskych krajinách. Porovnaním častí zákona týkajúcich sa videohier chceme hladat paralely s vnímaním češtiny v slovenských zákonoch, ako aj s vnímaním lokalizácie videohier. Zistenými skutočnostami chceme poukázat' na (ne)možnost' lokalizovat' a prekladat' hry aj pre malé trhy, ktorých jazyky sú si nesmierne podobné.

Okrem spomenutých problémov, ktoré prispievajú k pretrvávajúcemu nedostatku lokalizácie a prekladov videohier pre detských recipientov do slovenského jazyka, sa plánujeme venovat aj lokalizácii a prekladu videohier do málo rozšírených jazykov. Dúfame, že náš výskum bude mat prínos nielen pre slovenskú translatológiu, ale aj pre budúcich výskumníkov z iných krajín.

\section{Záver}

Lokalizácii videohier sa dosial' na Slovensku nevenovala dostatočná pozornost’ a v rámci slovenskej translatológie je stále vo svojich začiatkoch, napriek zaužívanej prekladatel'skej tradícii v zahraničí. V tomto príspevku sme prezentovali náš výskum loka-

8 https://pegi.info/what-do-the-labels-mean [cit. 31. 1. 2019]. 
lizácie videohier, ktorý sme začali v roku 2015. Príspevok sme rozdelili do štyroch kapitol. V prvej kapitole sme stručne charakterizovali skúmanú problematiku, pričom sme poukázali na pridané vlastnosti videohier, ktorá ich odlišuje od audiovizuálnych diel. V druhej kapitole sme sa zamerali na detského recipienta, pričom sme poukázali na slovenskú legislatívu, ktorá ukladá distribútorom videohier povinnost' lokalizovat’ videohry pre deti do 12 rokov. V tretej kapitole, ktorú členíme na štyri podkapitoly, sme priblížili závažné zistenia nášho doterajšieho výskumu Venovali sme sa v nej otázkam lokalizácie, slovenského trhu, prekladatel’ov videohier a záujmu prekladatel’ov i hráčov o lokalizáciu. Vo štvrtej kapitole napokon upriamujeme pozornost̉ na náš aktuálny výskum a na orientáciu na detského recipienta. Kedže lokalizácia videohier nemá v slovenskej legislatíve dostatočné zastúpenie a lokalizovat by sa mali iba videohry pre deti do 12 rokov, rozhodli sme sa upriamit pozornost’ na tieto skutočnosti a skúmat’ špecifiká lokalizácie detských videohier do slovenčiny.

Skúmaná problematika ponúka množstvo tém, na ktoré sa dá nahliadat’ z rôznych perspektív prístupov. Či už ide o teoretické základy, ako je vymedzenie herných prvkov, platforiem, typu detských hier, až po praktické príklady a kritiku prekladu, lokalizácia videohier má čo ponúknut'. Dúfame, že náš výskum bude prínosom pre slovenskú translatológiu, a že sa k výskumu tejto oblasti pridá mnoho d’alších výskumníkov.

\section{Podakovanie}

Tento príspevok vznikol v rámci projektu VEGA 2/0166/19 Preklad ako súčast’ dejín kultúrneho priestoru III.

\section{LITERATÚRA A ELEKTRONICKÉ ZDROJE}

Bernal-Merino, M. (2015) Translation and Localisation in Video Games. Making Entertainment Software Global, London: Routledge.

Chandler, H. - Deming, S. (2012) The Game Localization Handbook, London: Jones \& Bartlett Learning, LLC.

Cabajová, P. (2019) Lokalizácia videohier v Nitrianskom regióne, bakalárska práca, Nitra: FF UKF, 2019.

Chlebeková, J. (2014) Rozvoj komunikatívnych kompetencií dietata v spolupráci materskej školy a rodiny, Bratislava: Metodicko-pedagogické centrum.

Esselink, B. (2000) A Practical Guide to Localization, vol. 4, Amsterdam/Philadelphia: John Benjamins Publishing Company.

Janecová, E. (2014) 'Titulkovanie pre nepočujúcich a sluchovo postihnutých: V čom je vlastne problém?', in Preklad a tlmočenie 11 - Má translatológia dnes ešte čo ponúknut? I., Banská Bystrica: Belianum, 141-150.

Kabát, M. (2019) 'Pár poznámok k špecifikám lokalizácie’, in Prekladatel'ské listy 8, Bratislava: Univerzita Komenského v Bratislave, 21-34.

Kent, S. L. (2001) The Ultimate History of Video Games: From Pong to Pokemon-The story behind the craze that touched our lives and changed the world, New York: Three Rivers Press.

Koscelníková, M. (2017) Audiovisual Translation - Video Games: Subtitling of Video Games in Slovakia, diplomová práca, Banská Bystrica: FF UMB.

Koscelníková, M. (2018a) 'Titulkovanie videohier na Slovensku’, in Prekladatel'ské listy 7, Bratislava: Univerzita Komenského v Bratislave, 55-70. 
Koscelníková, M. (2018b) 'Neoficiálne v oficiálnom alebo o slovenskom preklade videohry Sherlock Holmes versus Arsène Lupin', in Kritika prekladu (1), Banská Bystrica: Belianum, 81-102.

Kulbak, G. (2018) 'Globalizácia, internacionalizácia, lokalizácia a preklad', in Odborný preklad a podporné inštrumentárium, Prešov: Filozofická fakulta, 59-75.

Lommel, A. (2003) The Localization Industry Primer (2), Féchy: The Localization Industry Standards Organization.

Mangiron, C. - O’Hagan, M. (2006) 'Game localisation: unleashing imagination with restricted translation', The Journal of Specialised Translation 6: 10-21.

Marčanová, K. (2018) Porovnanie lokalizácie videohier a neherného softvéru na Slovensku, diplomová práca. Bratislava: FF UK.

Pym, A. (2004) The Moving Text: Localization, Translation and Distribution. Amsterdam: John Benjamins Publishing Company, 2004.

Pym, A. (2013) Localization, Training, and Instrumentalization. Version 3, http://usuaris.tinet.cat/apym /on-line/training/2013_localization.pdf [access: 31. 1. 2019].

Rakšányová, J. (2012) '3D v preklade i translatológii alebo ostáva miesto pre prekladatel'skú etiku?', in Preklad a tlmočenie 10, Banská Bystrica: Univerzita Mateja Bela, 47-53.

Electronic Software Association: Essential Facts about the Computer and Video Game Industry (2018), http://www.theesa.com/wp-content/uploads/2018/05/EF2018_FINAL.pdf [access: 31. 1. 2019].

--- (2017), http://www.theesa.com/wp-content/uploads/2017/04/EF2017_FinalDigital.pdf [access: 31. 1.2019].

--- (2016), http://www.theesa.com/wp-content/uploads/2016/04/Essential-Facts-2016.pdf [access: 31. 1.2019].

--- (2015), http://www.theesa.com/wp-content/uploads/2015/04/ESA-Essential-Facts-2015.pdf [access: 31. 1.2019].

--- (2014), http://www.theesa.com/wp-content/uploads/2014/10/ESA_EF_2014.pdf [access: 31. 1. 2019].

--- (2013), https://www.isfe.eu/sites/isfe.eu/files/attachments/esa_ef_2013.pdf [access: 31. 1. 2019].

--- (2012), https://www.isfe.eu/sites/isfe.eu/files/attachments/esa_ef_2012.pdf [access: 31. 1. 2019].

--- (2011), https://www.isfe.eu/sites/isfe.eu/files/attachments/esa_ef_2011.pdf [access: 31. 1. 2019].

--- (2010), https://www.isfe.eu/sites/isfe.eu/files/attachments/esa_ef_2010.pdf [access: 31. 1. 2019].

--- (2009), https://library.princeton.edu/sites/default/files/2009.pdf [access: 31. 1. 2019].

--- (2008), https://library.princeton.edu/sites/default/files/2008.pdf [access: 31. 1. 2019].

--- (2007), https://library.princeton.edu/sites/default/files/2007.pdf [access: 31. 1. 2019].

--- (2006), https://library.princeton.edu/sites/default/files/2006.pdf [access: 31. 1. 2019].

--- (2005), https://www.scribd.com/document/125495226/ESA-Essential-Facts-2005 [access: 31.1. 2019].

--- (2004), https://www.scribd.com/document/125494009/ESA-Essential-Facts-2004 [access: 31.1. 2019].

Zákon č. 40/2015 Z. z. o audiovízii, http://www.zakonypreludi.sk/zz/2015-40 [access: 31. 1. 2019].

Zákon č. 245/2008 Z. z. o výchove a vzdelávaní, http://www.zakonypreludi.sk/zz/2008-245 [access: 31. 1. 2019].

Zákon č. 270/1995 Z. z. o štátnom jazyku SR, http://www.zakonypreludi.sk/zz/1995-270 [access: 31. 1. 2019].

\section{RESUMEN}

El objetivo de nuestro papel es presentar el tema actual de localización de videojuegos en Eslovaquia. El tema todavía no ha encontrado su lugar en la academia eslovaca. La investigación extranjera es más compleja y ofrece muchos recursos teoréticos y prácticos. Las universidades extranjeras en proporción a Eslovaquia ofrecen programas académicas o cursos que se tratan de localización de videojuegos y hay muchos investigadores que la siguen siendo investigar por más de una década. Los videojuegos están localizados a muchos idiomas. En Eslovaquia no hay universidad que enseña localización de videojuegos, 
ni solo una asignatura optativa. A pesar de una situación desfavorable hay los investigadores jóvenes que empezaron a dedicar su vida profesional a la localización de un software como Kabát o Koscelníková. Hay muchos aspectos de traducción y localización de videojuegos para investigar y llamar la atención de academia eslovaca a este campo de traducción poco investigado. Nuestro papel muestra las especificida-

des de localización de videojuegos y la investigación que hemos empezado en 2015; apunta principales conclusiones y la investigación futura.

Mgr. Mária Koscelníková

Katedra translatológie, Filozofická fakulta, Univerzita Konštantína Filozofa v Nitre maria.koscelnikova@ukf.sk 